\title{
Evaluation of User Satisfaction with Academic Libraries Services Based on Students' Perspectives
}

\author{
Emmanuel Baffour Gyau'1, Jing Liu1, Obeng Kwakye² \\ ${ }^{1}$ Institute of Science and Technology Information, Jiangsu University, Zhenjiang, China \\ ${ }^{2}$ School of Finance and Economics, Jiangsu University, Zhenjiang, China \\ Email: papagyau24@gmail.com, liujing@ujs.edu.cn, kwabenakwakye1992@yahoo.com
}

How to cite this paper: Baffour Gyau, E., Liu, J. and Kwakye, O. (2021) Evaluation of User Satisfaction with Academic Libraries Services Based on Students' Perspectives. Open Access Library Journal, 8: e7783. https://doi.org/10.4236/oalib.1107783

Received: July 23, 2021

Accepted: August 15, 2021

Published: August 18, 2021

Copyright (๑) 2021 by author(s) and Open Access Library Inc.

This work is licensed under the Creative Commons Attribution International License (CC BY 4.0).

http://creativecommons.org/licenses/by/4.0/ (c) (i) Open Access

\begin{abstract}
Evaluation of user satisfaction is a significant determinant of library performance in terms of quality service delivery to ascertain and innovate where the library services need improvement. The main goal of the study is to evaluate user satisfaction of academic library services based on students' perspectives and determine the relationship between user satisfaction and the overall library service quality. The study adopted the survey research method and a user satisfaction questionnaire was developed to solicit data and responses from international students who are users of the Jiangsu University Library. A total of 283 responses were obtained through the simple random sampling technique. The solicited data were analyzed using frequency, percentage, tables, and charts. The results of the study indicate that users are satisfied with both library's support for learning and research, and the library's treatment of users and students rated the overall quality of services provided by the library as good. Pearson correlation analysis and multivariate analysis of variance (oneway MANOVA) were done to measure the relationships and effects between user satisfaction and the overall library service quality and the results show that library users' satisfaction has a positive and significant relationship and effect with the overall library service quality. However, the academic still has to improve its services because a few users are dissatisfied with the library's support for learning and research, and the library's treatment of users. The outcomes of the study will assist academic libraries to formulate effective strategies to ensure better delivery of quality services to the users to enhance their satisfaction, thereby attracting more users. This will also help academic libraries to regularly analyze user's satisfaction and their views on academic library services.
\end{abstract}




\section{Subject Areas}

Information Science, Library, Intelligence and Philology

\section{Keywords}

User Satisfaction, Library Services, Support, Treatment, Service Quality, Academic Library

\section{Introduction}

Every service-providing institution has its clients or customers to whom services are rendered to. The main goal of these institutions is to deliver quality services that will satisfy the needs of their customers. The educational industry as an example has students as their main customers and therefore obliged to render quality educational resources and services that satisfy students' academic needs. This establishes that the achievement and failure of any educational institution are mainly dependent on students' satisfaction. However, academic libraries which are part and the backbone of these educational institutions also has a major part to play for every educational institution to achieve its set objectives. They are therefore obligated to deliver quality library services to satisfy student study, learning, and research needs for the development of the institution, community, and the nation as a whole. It is therefore clear and obvious that clients', customers', or users' satisfaction is an integral and significant value to hold on for any serviceproviding institution.

Furthermore, customer satisfaction is defined by [1], as assessing a product or service to determine if it meets the needs and desires of the customers being delivered to. This means that failure to meet their set standards and expectations results in dissatisfaction. Altman and Hernon [2], stated that sometimes a customer may be satisfied because the library staff was polite even though his or her need was not met. He therefore, states that customers' satisfaction may or might not be directly related to the performance of a library on a specific occasion. The current study however considers the library's support for users in terms of service provision and how the library treats its users.

In addition, user satisfaction and service quality are both unique variables that need ultimate attention, however, they can be connected significantly. [3], the developers of the SERVQUAL model for measuring service quality are of the view that customer satisfaction is the precursor to service quality. [4] studied the quality of service and satisfaction in Malaysian university libraries and they established that the five dimensions of service quality proposed by [3], have a significant effect on users satisfaction. User satisfaction can therefore be summed up briefly as the satisfaction users obtain from utilizing the library's range of information resources and services to accomplish their everyday needs. This means that rendering quality services to these users will significantly influence their sa- 
tisfaction with the services rendered to them. This will therefore increase user's library usage frequency and also attract more users [5]. It is therefore important to evaluate user satisfaction with academic library services from the student's viewpoint to determine if their needs are being met and also if the library services need improvements.

Any service-providing organization strives to render quality services that will satisfy its customers. Academic libraries are no exception as they strive always to innovate and deliver better and quality library and information services to their users. Furthermore, academic library services are supposed to satisfy their users' (students, teachers, faculty workers, librarians, etc.) expectations, their learning, teaching, and research needs because without these users utilizing these resources and services, they will be at waste and redundant. Moreover, from the statement above, it is important to note that long-term innovations and improvements of library services will be determined by evaluating users' satisfaction to ascertain the level of satisfaction with library services. Since students are the majority users of any academic library, it is significant to acknowledge their views and needs, and this study, therefore, considers their perspectives on the services rendered to them and if they are satisfied with these services. The study however regards the perspectives and satisfaction levels of the international students who uses the Jiangsu University Library. The study therefore seeks to ascertain if these diverse groups of students and users are satisfied with the services rendered to them by the academic libraries. The primary goal of the study is to evaluate user satisfaction with academic library services based on students' perspectives. However, the study is guided by these specific goals:

1) Evaluate the levels of user satisfaction with the library's support for learning and research, and the library's treatment of users.

2) To rate the overall library service quality.

3) Determine the relationship between the overall library service quality and user satisfaction.

\section{Literature Review}

User satisfaction is one of the main determinants of academic libraries' performance in delivering quality to the users. The main objective of all academic libraries is to deliver quality services to satisfy the needs of all their users being it teachers/lecturers, students, and library staff to assist them in their teaching, learning, and conducting scientific researches for the development of the library, the university, and the nation as a whole. It is therefore eminent for academic libraries which are the main brain behind the learning and research process of university institutions to satisfy the needs of the users of the library by rendering quality services to users and also conducting regular user surveys to elicit their views and their satisfaction for better improvement on current services.

According to [6], conducted an evaluation study on user satisfaction with library services and resources at the Medunsa campus of the University of Lim- 
popo. The study used a questionnaire to solicit data from students, academic staff, and administrative staff in the university. Their study discovered that users do make significant use of the library, its services and resources. Specifically, more users are satisfied with the information supplied by the library staff, the majority also indicated their satisfaction with the availability of staff, and the majority of the respondents indicated that they are satisfied with the help they receive from the library staff. However, the user gave recommendations on improving some services to meet the current information age even though they are satisfied. Some of these services included journal collection, photocopy machines, improvement of the internet service, an increase of library hours, and improvement of the services from library staff. Therefore, regular surveys and orientations should be conducted to ensure that users are always satisfied with academic library services and resources. The study tries to solicit data to determine satisfaction levels of the international students, the heterogeneous group of library users. This is because this particular group also uses academic libraries hugely and is among the majority users of the academic library services.

Furthermore, [7], examined how users of the College of Health Sciences Library at the Niger Delta University in Nigeria are satisfied with the library information resources and services rendered to them. Their study adopted the survey research design and a self-designed questionnaire was used to collect data through the random sampling technique. The outcomes of their study showed that users were satisfied with the book borrowing services of the library, the quick library material renewal process, and better and long hours of online activities in the library. It also found that users were dissatisfied with the limited reference contents discussed in various topics, both national and international journals because they were outdated. They recommended that the library should improve on the bindery services section, computer literacy skill for users, electronic information services and photocopying services this are avenues which the library can use in generating internal funds to develop its resources and services to users and the need to train library staff to improve on the library services rendered to library users.

Also, [8], conducted a study on user satisfaction with academic libraries services at the Redeemer's University based on academic staff and students' perspectives. She adopted the survey research method for the study and developed a questionnaire to elicit data from academic staff and students. The study concluded that users of Redeemer's University library were satisfied with the library services, however, there is need for improvement in the services provided by the library. She recommended that students should be sensitized to the importance and type of materials in the library during library orientation and how they can use the materials for assignment and research work. Also, the management of Redeemer's University library should endeavor to seek the opinion of users as to how the library services could further be improved and seek an audience with the academic staff on what the library should provide. Our study rather considers the 
opinions, views, and perspectives of the international students who use academic libraries on how satisfied they are and how they rate the quality of the overall library service rendered to them.

Furthermore, [9], studied user's satisfaction with India's seven IIT Libraries resources and services. They adopted the survey research method for their study. They found and inferred that most users of different IITs are satisfied with diverse library services such as lending of books, internet service, reference service, journals/periodicals circulations, E-journals, and online database services, and reservation service. However, they suggested that regular feedback from the faculty and students will also go a long way in improving the library services and their satisfaction can be met effectively. Our study also tries to find out whether international students who use the academic library are satisfied with diverse academic library services such as how library staffers treat them and how the library supports them in their learning and research works.

Moreover, customer perceptions of service quality, as well as satisfaction and loyalty towards Indian private healthcare were studied by [10]. They examined how service quality perceptions and customer satisfaction with services result in their loyalty towards service providers in the healthcare industry. Using a questionnaire survey to collect data from five Indian private hospitals, descriptive statistics, factor analysis, regression, and correlation statistics were employed to analyze customer perceived service quality and how it leads to loyalty towards service providers. The outcomes of their study revealed that there is a positive relationship between the service provider and the customer, quality facilities, and the interaction with supporting staff, and customer satisfaction. They concluded that the findings of the study will assist healthcare managers to formulate effective strategies to ensure a better quality of services to the customers. This study helps healthcare managers to build customer loyalty towards healthcare services, thereby attracting and gaining more customers. This study also employed the survey research method and tried to determine whether international students who use the academic library are satisfied with services rendered to them.

\section{Methodology}

The study adopted a survey research method to address the research questions. A user satisfaction survey questionnaire was developed and modified from the general satisfaction summary under the LIBQUAL $+{ }^{\mathrm{TM}}$ model. The survey questionnaire was used to gather data and to know how students rate the library services and their satisfaction with the library services. A five-point Likert scale technique from a scale of 1 - 5 where $(1=$ strongly disagree, $2=$ disagree, $3=$ neutral, $4=$ agree, and $5=$ strongly agree) was used to ascertain user satisfaction whiles ( 1 = extremely poor, $2=$ poor, $3=$ neutral, $4=$ good, and $5=$ extremely good) was used for rating the overall library service quality. According to [11], a target population is that population which the researcher wants to generalize results. The target population of the study consisted of all the international students in the 
Jiangsu University community. The questionnaire was administered to international students who use the services of the university library and a total of 283 respondents were obtained through a simple random sampling technique. Microsoft Excel and the Statistical Package for the Social Science (SPSS) were the statistical software used to analyze the solicited data. The researchers utilized analysis methods like frequencies, percentages, means, standard deviations, charts, and tables, Pearson's correlation analysis and multivariate analysis of variance (one-way MANOVA) with the help of the SPSS version 25.

\section{Results}

The survey results are based on the opinions and responses of 283 academic library users. The collected data comprises of 203 (71.7\%) male and 80 (28.3\%) female as well as $75(26.5 \%)$ undergraduates, 161 (56.9\%) masters, 45 (15.9\%) doctorate $(\mathrm{PhD})$, and others $2(0.7 \%)$ being post doctorate or exchange program international students who are users of the Jiangsu University Library. Descriptive statistics, frequency tables and charts were utilized to display user satisfaction and rate the overall library service quality. Both the Pearson correlation analysis and multivariate analysis of variance (one-way MANOVA) were done to measure the relationships and effects between user satisfaction and the overall library service quality based on a $95 \%$ confidence interval and 0.05 alpha levels.

\subsection{Descriptive Statistics}

Summary of Table 1 display the indicators for the variables, being satisfied with the library's support for learning and research, library's treatment of users, and rating the overall library service quality separately. Each one of the variables from Table 2, as expressed is converted into a distinctive logarithm. The parameters used for the descriptive statistics included, mean as the central tendency, standard deviation, skewness, and kurtosis. However, the mean and standard deviation was the two main parameters considered for the study. Interestingly, Table 1 reports that, for the satisfaction variables used in the investigation, satisfaction with library's support for learning and research, and satisfaction with library's treatment of users are normally 3.85 and 3.90 with standard deviations of 0.843 and 0.773 respectively and individually. Conversely, the overall library service quality when compared with each variable has a base average estimate of 4.03 and a standard deviation of 0.522 . Satisfaction with the library's support for learning and research with the highest estimated standard deviation of 0.843 implies that satisfaction with the library's support for learning and research is positively affected by the overall library service quality higher than satisfaction with the library's treatment of users. These findings show that the respondents are satisfied with library's support for learning and research, satisfied with the library's treatment of users, and rate that the overall library service quality as good. With regards to the slope, both satisfaction variables are skewed to the left and the overall library service quality is skewed to the right. About kurtosis, both satisfaction with the library's 
Table 1. Descriptive statistics.

\begin{tabular}{lcclcc}
\hline Variables & $\mathrm{N}$ & Mean & Standard Deviation & Skewness & Kurtosis \\
\hline $\begin{array}{l}\text { Satisfied with library's support for } \\
\text { learning and research }\end{array}$ & 283 & 3.85 & 0.843 & -0.385 & -0.396 \\
$\begin{array}{l}\text { Satisfied with library's treatment } \\
\text { of users }\end{array}$ & 283 & 3.90 & 0.773 & -0.391 & -0.123 \\
$\begin{array}{l}\text { Overall library service quality } \\
283\end{array}$ & 4.03 & 0.522 & 0.042 & 0.704 \\
\hline
\end{tabular}

Note: " $\mathrm{N}$ " is the total number of respondents.

Table 2. Levels of user satisfaction.

\begin{tabular}{|c|c|c|c|c|c|c|c|c|c|c|c|c|}
\hline \multirow[t]{2}{*}{ Variables } & \multicolumn{2}{|c|}{$\begin{array}{l}\text { Strongly } \\
\text { Agree }\end{array}$} & \multicolumn{2}{|c|}{ Agree } & \multicolumn{2}{|c|}{ Neutral } & \multicolumn{2}{|c|}{ Disagree } & \multicolumn{2}{|c|}{$\begin{array}{l}\text { Strongly } \\
\text { Disagree }\end{array}$} & \multicolumn{2}{|c|}{ TOTAL } \\
\hline & f & $\%$ & $\mathrm{f}$ & $\%$ & $\mathrm{f}$ & $\%$ & $\mathrm{f}$ & $\%$ & $f$ & $\%$ & $\mathrm{f}$ & $\%$ \\
\hline $\begin{array}{l}\text { Satisfied with the } \\
\text { library's support for } \\
\text { learning and research }\end{array}$ & 63 & 22 & 133 & 47 & 68 & 24 & 19 & 7 & 0 & 0 & 283 & 100 \\
\hline $\begin{array}{l}\text { Satisfied with the } \\
\text { library's treatment of users }\end{array}$ & 60 & 21 & 148 & 53 & 63 & 22 & 12 & 4 & 0 & 0 & 283 & 100 \\
\hline
\end{tabular}

Note: "f” and “\%” represent frequency and percentage of responses respectively.

support for learning and research and satisfaction with the library's treatment of users have negative values indicating a flat platykurtic distribution whiles the overall library service quality is positive indicating fatter and peaked leptokurtic distribution.

\subsection{User Satisfaction with the Library's Support and Treatment of Users}

Users were asked to rate their level of satisfaction with library services based on their satisfaction with the library's support for their learning and research and satisfaction with the library's treatment of users employing the five Likert scale being strongly agreed, agree, neutral, disagree, and strongly disagree. Most of the respondents 63 (22\%) strongly agree and $133(47 \%)$ agree that they are satisfied with the library's support for their learning and $19(7 \%)$ of the respondents disagree and are dissatisfied with the library's support for their learning. 68 (24\%) of the users are neutral and $0(0 \%)$ strongly disagree as shown in Table 2 and Figure 1. The outcomes and findings are evident the most of the users of the academic libraries are satisfied with the library's support for their learning. This variable of user satisfaction includes the availability of current books/material in print and electronic, easy-to-use library equipment, easily accessible and user-friendly website, a comfortable study environment, etc.

Also, the majority of the respondents 60 (21\%) strongly agree and 148 (53\%) agree that they are satisfied with the library's treatment of users and $12(4 \%)$ of the respondents disagree and are dissatisfied with the library's treatment of users. $63(22 \%)$ of the users are neutral and $0(0 \%)$ strongly disagree as shown in Table 2 and Figure 1. The outcomes and findings are evident the majority of the 


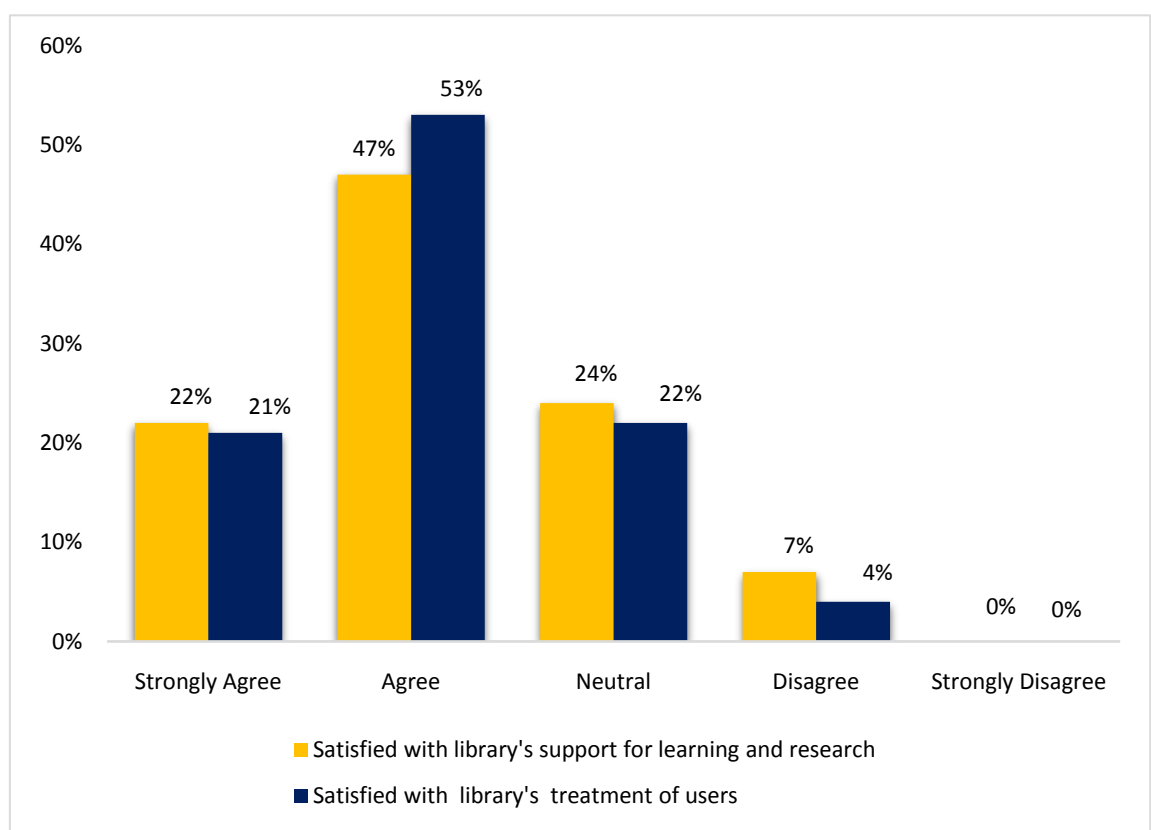

Figure 1. Satisfaction with the library's support and treatment.

users of academic libraries agree and are satisfied with the library's support for their learning. This variable of user satisfaction also includes how library employees treat library users politely, caring, respectful, courteous, being knowledgeable about user needs, dependable to solve user problems, willing and ready to assist users, etc.

Table 3 below further depicts the user satisfaction within the academic level of the respondents. The master students are the majority of respondents who strongly agree $42(26.10 \%)$ and agree $72(44.70 \%)$ with being satisfied with the library's support for learning and research. The respondents who are undergraduates have the largest number of respondents 9 (12\%) who disagree with being satisfied with the library's support for learning and research. Also, the respondents who are master students are the majority who strongly agree 34 (21.10\%) and agree 90 (55.90\%) with being satisfied with the library's treatment of users. However, they are also the largest group $6(3.70 \%)$ that disagree with being satisfied with the library's treatment of users as shown in Table 3. Furthermore, it was also observed that none of the respondents within any of the academic level groups are strongly dissatisfied with both library's support for learning and research and the library's treatment of users.

\subsection{Rating the Overall Library Service Quality}

Users were also asked to rate the overall library service quality based on five Likert scale: extremely good, good, undecided, poor, and extremely poor. The results show that $43(15 \%)$ and $206(73 \%)$ of the respondents rate the overall library service quality as extremely good and good respectively. $34(12 \%)$ of the respondents are undecided on the library service quality and $0(0 \%)$ of the respondents 
rated the quality of the service provided by the library extremely poor or poor as shown in Table 4 and Figure 2. The outcomes and findings are evidence that the majority of the users of academic libraries rate the overall quality of the service provided by the library as good.

Table 5 also shows the overall library service quality ratings within the academic level of the respondents. The majority of respondents who rate the overall library service quality to be extremely good $27(16.80 \%)$ and good $123(76.40 \%)$ are master students. The largest number of respondents who are undecided 12 (26.70\%) about the overall library service quality level are doctorate (Ph.D.) students. Moreover, none of the academic level group rated the overall library service quality to be poor or extremely poor as depicted in Table 5 .

Table 3. Frequency and percentage of user satisfaction levels based on academic level.

\begin{tabular}{|c|c|c|c|c|c|}
\hline $\begin{array}{l}\text { User satisfaction } \\
\text { variables }\end{array}$ & Academic Level & Disagree & Neutral & Agree & Strongly Agree \\
\hline \multirow{10}{*}{$\begin{array}{l}\text { Satisfied with the } \\
\text { library's support } \\
\text { for learning } \\
\text { and research }\end{array}$} & Undergraduate & 9 & 13 & 32 & 21 \\
\hline & & $12.00 \%$ & $17.30 \%$ & $42.70 \%$ & $28.00 \%$ \\
\hline & Master & 8 & 39 & 72 & 42 \\
\hline & & $5.00 \%$ & $24.20 \%$ & $44.70 \%$ & $26.10 \%$ \\
\hline & Doctorate (Ph.D.) & 2 & 14 & 29 & 0 \\
\hline & & $4.40 \%$ & $31.10 \%$ & $64.40 \%$ & $0.00 \%$ \\
\hline & Other & 0 & 2 & 0 & 0 \\
\hline & & $0.00 \%$ & $100.00 \%$ & $0.00 \%$ & $0.00 \%$ \\
\hline & Total & 19 & 68 & 133 & 63 \\
\hline & & $6.70 \%$ & $24.00 \%$ & $47.00 \%$ & $22.30 \%$ \\
\hline \multirow{10}{*}{$\begin{array}{l}\text { Satisfied with } \\
\text { the library's } \\
\text { treatment } \\
\text { of users }\end{array}$} & Undergraduate & 4 & 22 & 26 & 23 \\
\hline & & $5.30 \%$ & $29.30 \%$ & $34.70 \%$ & $30.70 \%$ \\
\hline & Master & 6 & 31 & 90 & 34 \\
\hline & & $3.70 \%$ & $19.30 \%$ & $55.90 \%$ & $21.10 \%$ \\
\hline & Doctorate (Ph.D.) & 0 & 10 & 32 & 3 \\
\hline & & $0.00 \%$ & $22.20 \%$ & $71.10 \%$ & $6.70 \%$ \\
\hline & Others & 2 & 0 & 0 & 0 \\
\hline & & $100.00 \%$ & $0.00 \%$ & $0.00 \%$ & $0.00 \%$ \\
\hline & Total & 12 & 63 & 148 & 60 \\
\hline & & $4.20 \%$ & $22.30 \%$ & $52.30 \%$ & $21.20 \%$ \\
\hline
\end{tabular}

Table 4. Rating overall quality of the service provided by the library.

\begin{tabular}{|c|c|c|c|c|c|c|c|c|c|c|c|c|}
\hline \multirow[t]{2}{*}{ Variable } & \multicolumn{2}{|c|}{$\begin{array}{l}\text { Extremely } \\
\text { Good }\end{array}$} & \multicolumn{2}{|c|}{ Good } & \multicolumn{2}{|c|}{ Undecided } & \multicolumn{2}{|c|}{ Poor } & \multicolumn{2}{|c|}{$\begin{array}{l}\text { Extremely } \\
\text { Poor }\end{array}$} & \multicolumn{2}{|c|}{ TOTAL } \\
\hline & $\mathrm{f}$ & $\%$ & f & $\%$ & $\mathrm{f}$ & $\%$ & $\mathrm{f}$ & $\%$ & $\mathrm{f}$ & $\%$ & $\mathrm{f}$ & $\%$ \\
\hline $\begin{array}{c}\text { The Overall Library } \\
\text { Service Quality }\end{array}$ & 43 & 15 & 206 & 73 & 34 & 12 & 0 & 0 & 0 & $0 \%$ & 283 & $100 \%$ \\
\hline
\end{tabular}

Note: "f" and “\%” represent frequency and percentage of responses respectively. 
Table 5. Frequency and percentage of the overall library service quality ratings based on academic level.

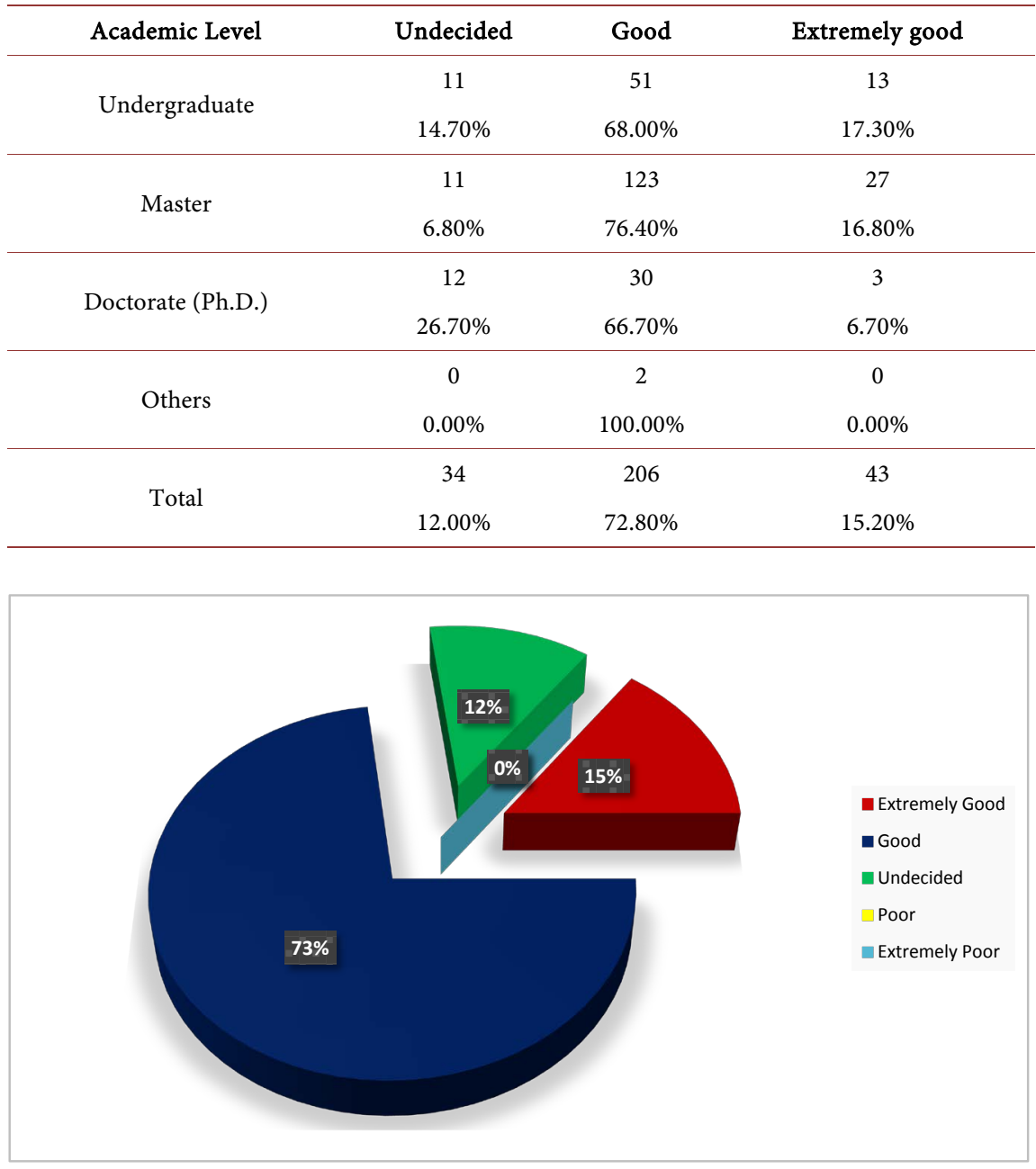

Figure 2. Rating overall library service quality.

\subsection{Relationship between User Satisfaction and the Overall Library Service Quality}

A Pearson's correlation analysis was conducted to explore the relationship between user satisfaction and service quality. The correlation analysis is depicted in Table 6. A significant positive correlation was established between being satisfied with the library's support for my learning and research and the overall library service quality $(r=0.261, p<0.01)$. It was also established that there was a significant positive correlation between being satisfied with the library's treatment of users and the overall library service quality $(r=0.368, p<0.01)$. Furthermore, a positive significant correlation was found between being satisfied with the library's support for my learning and being satisfied with the library's treatment of users $(r=0.502, p<0.01)$ as shown in Table 6 below. This is because these two variables measure the same thing. This implies that these three variables should be continuously emphasized by the respondents' library in evaluation operations because of their significance to service quality delivery in the li- 
brary.

In addition, the relationship and effect of the overall library service quality on user satisfaction was further ascertained by employing the multivariate analysis of variance (one-way MANOVA) to confirm and validate the correlation analysis. The user satisfaction variables: satisfaction with library's support for learning and research and satisfaction with library's treatment of users were used as dependent variables whiles the overall library service quality was the only fixed factor. The analysis employed Levene's Test of Equal Variance Assumed (Turkey'sb), Type III Sum of Squares, Partial Eta Squared (R squared), Adjusted R squared, $95 \%$ confident interval, and a significant level of 0.05 . The outcomes of the multivariate analysis are shown in Table 7 and Table 8. Table 7 shows the multivariate tests, where the actual results of the one-way MANOVA are found by looking at the second effect labeled "Overall library service quality" and the Wilks's Lambda row. To determine whether the one-way MANOVA was statistically significant we need to look at the "Sig." column. We can see from the table that we have a "Sig." value of 0.000 , which means $p<0.0005$. Therefore, it can be concluded that user satisfaction was significantly dependent on the overall library service quality $(p<0.0005)$. There was a statistically significant difference in user satisfaction based on the overall library service quality, $F(4,558)=12.85, p<0.0005$; Wilk's $\Lambda=$ 0.838, partial $\eta^{2}=0.084$ as shown in Table 7 .

Furthermore, to determine how the dependent variables differ from the independent variable, we need to look at the Tests of Between-Subjects Effects, which is displayed in Table 8. It is evident from Table 8 that the overall library service quality has a statistically significant effect on being satisfied with library's support for learning and research $\left(F(2,280)=11.68 ; p<0.0005\right.$; partial $\left.\eta^{2}=0.077\right)$ and being satisfied with library's treatment of users $(F(2,280)=25.30 ; p<$ 0.0005; partial $\eta^{2}=0.153$ ) as shown in Table 8. This clearly shows and confirms that the overall library service quality has a higher significant impact on being satisfied with the library's treatment of users than being satisfied with the library's support for learning and research.

Table 6. Correlation analysis of variables.

\begin{tabular}{|c|c|c|c|c|}
\hline Variables & & 1 & 2 & 3 \\
\hline \multirow[t]{3}{*}{$\begin{array}{l}\text { 1. Satisfaction with the library's } \\
\text { support for learning and research }\end{array}$} & Pearson Correlation & 1 & & \\
\hline & Sig. (2-tailed) & . & & \\
\hline & $\mathrm{N}$ & 283 & & \\
\hline \multirow[t]{3}{*}{$\begin{array}{l}\text { 2. Satisfaction with the } \\
\text { library's treatment of users }\end{array}$} & Pearson Correlation & $0.502^{\star *}$ & 1 & \\
\hline & Sig. (2-tailed) & 0 & . & \\
\hline & $\mathrm{N}$ & 283 & 283 & \\
\hline \multirow[t]{3}{*}{ 3. Library's overall service quality } & Pearson Correlation & $0.261^{\star *}$ & $0.368^{* *}$ & 1 \\
\hline & Sig. (2-tailed) & 0 & 0 & . \\
\hline & $\mathrm{N}$ & 283 & 283 & 283 \\
\hline
\end{tabular}

${ }^{* *}$ Correlation is significant at the 0.01 level (2-tailed). 
Table 7. Multivariate tests ${ }^{\mathrm{a}}$.

\begin{tabular}{|c|c|c|c|c|c|c|c|}
\hline \multicolumn{2}{|c|}{ Effect } & Value & $\mathbf{F}$ & $\begin{array}{c}\text { Hypothesis } \\
\text { df }\end{array}$ & $\begin{array}{c}\text { Error } \\
\text { df }\end{array}$ & Sig. & $\begin{array}{l}\text { Partial } \\
\text { Eta } \\
\text { Squared }\end{array}$ \\
\hline \multirow{4}{*}{ Intercept } & Pillai's Trace & 0.955 & $2939.433^{\mathrm{b}}$ & 2.000 & 279.000 & 0.000 & 0.955 \\
\hline & Wilks' Lambda & 0.045 & $2939.433^{\mathrm{b}}$ & 2.000 & 279.000 & 0.000 & 0.955 \\
\hline & Hotelling's Trace & 21.071 & $2939.433^{\mathrm{b}}$ & 2.000 & 279.000 & 0.000 & 0.955 \\
\hline & Roy's Largest Root & 21.071 & $2939.433^{\mathrm{b}}$ & 2.000 & 279.000 & 0.000 & 0.955 \\
\hline \multirow{4}{*}{$\begin{array}{l}\text { Overall library } \\
\text { service quality }\end{array}$} & Pillai's Trace & 0.162 & 12.306 & 4.000 & 560.000 & 0.000 & 0.081 \\
\hline & Wilks' Lambda & 0.838 & $12.852^{\mathrm{b}}$ & 4.000 & 558.000 & 0.000 & 0.084 \\
\hline & Hotelling's Trace & 0.193 & 13.395 & 4.000 & 556.000 & 0.000 & 0.088 \\
\hline & Roy's Largest Root & 0.193 & $26.984^{c}$ & 2.000 & 280.000 & 0.000 & 0.162 \\
\hline
\end{tabular}

a. Design: Intercept + Overall library service quality; b. Computed using alpha $=0.05 ;$ c. Exact statistic; d. The statistic is an upper bound on $\mathrm{F}$ that yields a lower bound on the significance level.

Table 8. Tests of between-subjects effects.

\begin{tabular}{|c|c|c|c|c|c|c|c|}
\hline Source & Dependent Variables & $\begin{array}{l}\text { Type III } \\
\text { Sum of } \\
\text { Squares }\end{array}$ & df & $\begin{array}{l}\text { Mean } \\
\text { Square }\end{array}$ & F & Sig. & $\begin{array}{c}\text { Partial } \\
\text { Eta } \\
\text { Squared }\end{array}$ \\
\hline \multirow{2}{*}{$\begin{array}{l}\text { Corrected } \\
\text { Model }\end{array}$} & $\begin{array}{l}\text { Satisfied with the library's } \\
\text { support for learning and research }\end{array}$ & $15.436^{\mathrm{a}}$ & 2 & 7.718 & 11.679 & 0.000 & 0.077 \\
\hline & $\begin{array}{l}\text { Satisfied with the library's } \\
\text { treatment of users. }\end{array}$ & $25.780^{\mathrm{b}}$ & 2 & 12.890 & 25.302 & 0.000 & 0.153 \\
\hline \multirow{2}{*}{ Intercept } & $\begin{array}{l}\text { Satisfied with the library's } \\
\text { support for learning and research }\end{array}$ & 2386.840 & 1 & 2386.840 & 3611.913 & 0.000 & 0.928 \\
\hline & $\begin{array}{l}\text { Satisfied with the library's } \\
\text { treatment of users. }\end{array}$ & 2476.781 & 1 & 2476.781 & 4861.730 & 0.000 & 0.946 \\
\hline $\begin{array}{l}\text { Overall } \\
\text { library }\end{array}$ & $\begin{array}{l}\text { Satisfied with the library's } \\
\text { support for learning and research }\end{array}$ & 15.436 & 2 & 7.718 & 11.679 & 0.000 & 0.077 \\
\hline $\begin{array}{l}\text { service } \\
\text { quality }\end{array}$ & $\begin{array}{l}\text { Satisfied with the library's } \\
\text { treatment of users. }\end{array}$ & 25.780 & 2 & 12.890 & 25.302 & 0.000 & 0.153 \\
\hline \multirow{2}{*}{ Error } & $\begin{array}{c}\text { Satisfied with the library's } \\
\text { support for learning and research }\end{array}$ & 185.031 & 280 & .661 & & & \\
\hline & $\begin{array}{l}\text { Satisfied with the library's } \\
\text { treatment of users. }\end{array}$ & 142.644 & 280 & .509 & & & \\
\hline \multirow{2}{*}{ Total } & $\begin{array}{l}\text { Satisfied with the library's } \\
\text { support for learning and research }\end{array}$ & 4391.000 & 283 & & & & \\
\hline & $\begin{array}{l}\text { Satisfied with the library's } \\
\text { treatment of users. }\end{array}$ & 4483.000 & 283 & & & & \\
\hline \multirow{2}{*}{$\begin{array}{l}\text { Corrected } \\
\text { Total }\end{array}$} & $\begin{array}{l}\text { Satisfied with the library's } \\
\text { support for learning and research }\end{array}$ & 200.466 & 282 & & & & \\
\hline & $\begin{array}{l}\text { Satisfied with library's } \\
\text { treatment of users. }\end{array}$ & 168.424 & 282 & & & & \\
\hline
\end{tabular}

a. R Squared $=0.077$ (Adjusted R Squared $=0.070)$; . R Squared = 0.153 (Adjusted R Squared = 0.147); . Computed using alpha $=0.05$. 


\section{Discussion}

The results of the study indicate that most of the respondents are generally satisfied with library's support for their learning and research and also most of them are satisfied with library's treatment of users. The study revealed that most of the respondents $63(22 \%)$ strongly agree and $133(47 \%)$ agree that they are satisfied with the library's support for their learning and few 19 (7\%) of the respondents disagree and are dissatisfied with the library's support for their learning and research. 68 (24\%) of the users are neutral and $0(0 \%)$ strongly disagree. Moreover, the results show that most of the respondents $60(21 \%)$ strongly agree and 148 (53\%) agree that they are satisfied with the library's treatment of users and less $12(4 \%)$ of the respondents disagree and are dissatisfied with the library's treatment of users. $63(22 \%)$ of the users are neutral and $0(0 \%)$ strongly disagree. The results of the current study validate a previous study conducted by [7], on how users of the College of Health Sciences Library at the Niger Delta University in Nigeria are satisfied with the library information resources and services rendered to them. The results showed that users were satisfied with the book borrowing services of library, quick library material renewal process, and better and long hours of online activities in the library. It also found that users were dissatisfied with the limited reference contents discussed in various topics, both national and international journals because they were outdated. Also, a previous study by [9], on user's satisfaction with library resources and services in IIT libraries in India confirms the current study findings. Their research concluded that users of different IITs are satisfied with diverse library services, computers and software availability, digital sources/services, however, there is a need for improvement in the existing infrastructure and service provision of IIT libraries in India to meet users' satisfaction. In addition, the findings of this study conform to a study on library resources with services satisfaction based on students and faculties: in an institution by Rani [12]. The results of the study revealed that users were generally and highly satisfied with library resources and library services. It was also concluded that master students are the majority of respondents who strongly agree and agree with being satisfied with the library's support for learning and research. The respondents who are undergraduates have the largest number of respondents who disagree with being satisfied with the library's support for learning and research. Also, the respondents who are master students are the majority who strongly agree and agree with being satisfied with the library's treatment of users. However, they are also the largest group that disagrees with being satisfied with the library's treatment of users. It is therefore evident that master students are the majority user of the Jiangsu University Library confirming the findings of the study by [5].

Furthermore, the study unveiled that the overall rating of the quality of library services delivered to users of academic libraries are good. The results showed that $43(15 \%)$ and $206(73 \%)$ of the respondents rate the overall library service quality as extremely good and good respectively. 34 (12\%) of the respondents are 
undecided on the library service quality and $0(0 \%)$ of the respondents rated the quality of the service provided by the library extremely poor or poor. According to these results it follows that, international students are generally satisfied and rate the overall of quality service provided by the library as good. This outcome is consistent with several research studies that researched and found the overall service quality of libraries to be good [13] [14] [15]. A study that had a negative result is that by [16] who studied the impediments to qualitative services in four academic libraries in Nigeria. It was revealed that the majority of respondents who rate the overall library service quality to be extremely good and good are master students. The largest number of respondents who are undecided about the overall library service quality level is doctorate (Ph.D.) students.

Moreover, the study unveiled that the overall library service quality has a significant effect on user satisfaction and a positive one to be precise. This means an increase in service quality will increase satisfaction and vice versa. The results showed that overall library service quality has a significant relationship and effect on both satisfaction with the library's support for users learning and research and satisfaction with the library's treatment of users. From the results, international students' satisfaction with library services has a positive significant relationship with the overall quality of service being delivered to them. These findings are consistent with several research studies that demonstrated and affirmed that there is a significant relationship between service quality and satisfaction. [17], assessed the influence that service quality has on satisfaction within campus recreation. The study used performance-based measures and concluded that service quality and overall satisfaction have a significant relationship. There are several other studies on the relationship between user satisfaction and service quality with the conclusion that there is a significant relationship between these two variables. [8] [10] [18] [19] [20] [21] The discussion above on the overall library service quality and the user satisfaction variables clearly establishes a significant correlation between the overall library service quality and user satisfaction variables. Therefore, university libraries should consider seriously the effect of service quality delivery has on their users to meet their needs.

\section{Conclusions and Recommendations}

The study provides empirical evidence on user satisfaction of services provided by academic libraries and rating the overall library service quality. User satisfaction of library services was grouped into two; being satisfied with the library's support for learning, satisfied with the library's treatment of users, and also users rating the overall quality of services. The study suggests that the library is a more preferred place for international students to go study and make use of the academic library services for educational purposes. Therefore, quality services are needed to boost user satisfaction.

The study revealed that academic users are satisfied with both library's support for learning and library's treatment of users. This is statistically evident when more 
than half of the respondents strongly agreed and agree respectively to satisfaction with both the library's support for learning and the library's treatment of users. However, some respondents were undecided and others disagreed with satisfaction with both the library's support for learning and the library's treatment of users. This is a problem and should be looked into because it means that the library services have minor flaws which may be associated with the language barrier relating to librarians and tools and equipment which should be improved to achieve maximum satisfaction even though more users are satisfied with the services. These hidden problems can be improved by conducting frequent user surveys to obtain the views and opinions of users to be able to locate loopholes in the services rendered. Regular orientations to both library staff and users on how to handle and deal with users of different backgrounds and how to better identify and understand services respectively. This will improve library staff knowledge on how to handle users and understand their diverse views and needs and also treat them politely.

Also, users rated the overall quality of the service provided by the library as good. The outcomes and findings are evidence that the majority of the users of academic libraries rate the overall quality of the service provided by the library as extremely good and good. No user rated the overall service quality to be poor or extremely poor meaning the overall service quality is undoubtedly good. Meanwhile, a few respondents are undecided and their needs and views must be solicited to improve where the services fall short for them. This can be done through a regularly service quality survey based on user evaluations to solicit user needs and expectations of the services.

Lastly, the study shows that academic library users' satisfaction has a positive and significant relationship and effect with the overall quality of services the library provides. This means that an increase in service quality will increase user satisfaction significantly and a decrease in service quality will also significantly decrease user satisfaction. This is a scientific advantage and reference to academic libraries to render better and quality services for maximum user satisfaction. It is therefore important that the library maintains its current performance while innovating to better service quality levels from time to time to satisfy the needs of the users.

\section{Conflicts of Interest}

The authors declare no conflicts of interest.

\section{References}

[1] Zeithaml, V.A. and Bitner, M.J. (2003) Services Marketing: Integrating Customer Focus across the Firm. 3rd Edition, McGraw-Hill, Boston, New York.

[2] Altman, E. and Hernon, P. (1998) Service Quality and Customer Satisfaction Do Matter. American Libraries, 29, 53-54.

[3] Parasuraman, A., Zeithaml, V.A. and Berry, L.L. (1988) Servqual: A Multiple-Item Scale for Measuring Consumer Perceptions of Service Quality. Journal of Retailing, 64, 12- 
40.

[4] Hanaysha, J.R., Abdullah, H.H. and Warokka, A. (2011) Service Quality and Students' Satisfaction at Higher Learning Institutions: The Competing Dimensions of Malaysian Universities' Competitiveness. The Journal of Southeast Asian Research, 2011, Article ID: 855931. https://doi.org/10.5171/2011.855931

[5] Gyau, E.B., Jing, L. and Akowuah, S. (2021) International Students Library Usage Frequency Patterns in Academic Libraries: A User Survey at Jiangsu University Library. Open Access Library Journal, 8, Article No. e7610. https://doi.org/10.4236/oalib.1107610

[6] Motiang, I.P. (2014) An Evaluation of User Satisfaction with Library Services at the University of Limpopo, Medunsa Campus (Medical University of Southern Africa). Arabian Journal of Business and Management Review (OMAN Chapter), 3, 41-58. https://doi.org/10.12816/0016519

[7] Tiemo, P.A. and Ateboh, B.A. (2016) Users' Satisfaction with Library Information Resources and Services: A Case Study College of Health Sciences Library Niger Delta University, Amassoma, Nigeria. Journal of Education and Practice, 7, 54-59.

[8] Adeniran, P. (2011) User Satisfaction with Academic Libraries Services: Academic Staff and Students Perspectives. International Journal of Library and Information Science, 3, 209-216. https://doi.org/10.5897/IJLIS11.045

[9] Singh, K. and Kuri, R. (2017) User's Satisfaction with Library Resources and Services: A Case Study of IIT Libraries in India. International Research: Journal of Library \& Information Science, 7, 496-509.

[10] Kondasani, R.K.R. and Panda, R.K. (2015) Customer Perceived Service Quality, Satisfaction and Loyalty in Indian Private Healthcare. International Journal of Health Care Quality Assurance, 28, 452-467. https://doi.org/10.1108/IJHCQA-01-2015-0008

[11] Maxwell, J.A. and Chmiel, M. (2014) Generalization in and From Qualitative Analysis. In: Flick, U., Ed., The SAGE Handbook of Qualitative Data Analysis, SAGE Publications Inc., Thousand Oaks, 540-553. https://doi.org/10.4135/9781446282243.n37

[12] Rani, P. (2018) A Study on Library Resources with Services Satisfaction Based on Students and Faculties: In an Institution. International Journal of Applied Engineering Research, 13, 15443-15450.

[13] Hiller, S. (2001) Assessing User Needs, Satisfaction, and Library Performance at the University of Washington Libraries. Steve Library Trends, 49, 605-625.

[14] Nitecki, D.A. and Hernon, P. (2000) Measuring Service Quality at Yale University's Libraries. The Journal of Academic Librarianship, 26, 259-273.

https://doi.org/10.1016/S0099-1333(00)00117-8

[15] Thapisa, A. and Gamini, V. (1999) Perceptions of Quality Service at the University of Botswana Library: What Nova Says. Library Management, 20, 373-383. https://doi.org/10.1108/01435129910285145

[16] Opaleke, J. (2002) Impediments to Qualitative Services in Academic Libraries in Nigeria: An Examination of Libraries in Four Institutions in Kwara State. Library Review, 51, 100-106. https://doi.org/10.1108/00242530210418864

[17] Ott, M. (2008) An Analysis of the Impact of Service Quality on Satisfaction, Value, and Future Intentions within Campus Recreation Using Performance-Based Measures. University of New Hampshire, Durham.

[18] Griffiths, J.R., Johnson, F. and Hartley, R.J. (2007) User Satisfaction as a Measure of 
System Performance. Journal of Librarianship and Information Science, 39, 142-152. https://doi.org/10.1177\%2F0961000607080417

[19] Kassim, N.A. (2017) Evaluating Users' Satisfaction on Academic Library Performance. Malaysian Journal of Library \& Information Science, 12, 101-115.

[20] Chen, C.-F. (2008) Investigating Structural Relationships between Service Quality, Perceived Value, Satisfaction, and Behavioral Intentions for Air Passengers: Evidence from Taiwan. Transportation Research Part A: Policy and Practice, 42, 709-717. https://doi.org/10.1016/j.tra.2008.01.007

[21] Hanaysha, J.R., Dileep, K. and Hilman, H. (2012) Service Quality and Satisfaction: Study on International Students in Universities of North Malaysia. International Journal of Research in Management, 3, 116-133. 